\title{
Three new species of Varicorhinus (Pisces, Cyprinidae) from Africa
}

\section{K. E. Banister}

Department of Zoology, British Museum (Natural History), Cromwell Road, London SW7 5BD

\section{Introduction}

The genus Varicorhinus is contentious and a re-evaluation of it is in preparation. During the course of this work the existence of three new taxa became apparent and to avoid side issues and to make the larger work more coherent, they are described below.

\section{Varicorhinus jubae sp. nov.}

A recent sample of 13 fishes from the Juba river, near Sidam, Ethiopia consisted of 10 specimens of Barbus gananensis Vinciguerra and three specimens referable to Varicorhinus. No species of the latter genus have been recorded from the Juba system.

TYPICAL SERIES. Holotype BMNH 1976.7.1:13; two paratypes BMNH 1976.7.1:14-15, respectively of 135,101 and $77 \mathrm{~mm} \mathrm{SL}$. The fish were collected by Drs Yalden, Largen and Morris from Juba river, close to the Sidam-Bale bridge $05^{\circ} 45^{\prime} \mathrm{N}, 39^{\circ} 37^{\prime} \mathrm{E}$, altitude $1200 \mathrm{~m}$. The collectors describe the locality as 'permanently flowing river through Acacia woodland. The fish were caught in a shallow stretch where the water flows rapidly over shingle'.

ETYMology. The specific name alludes to the Juba river and is treated as a feminine Latin noun.

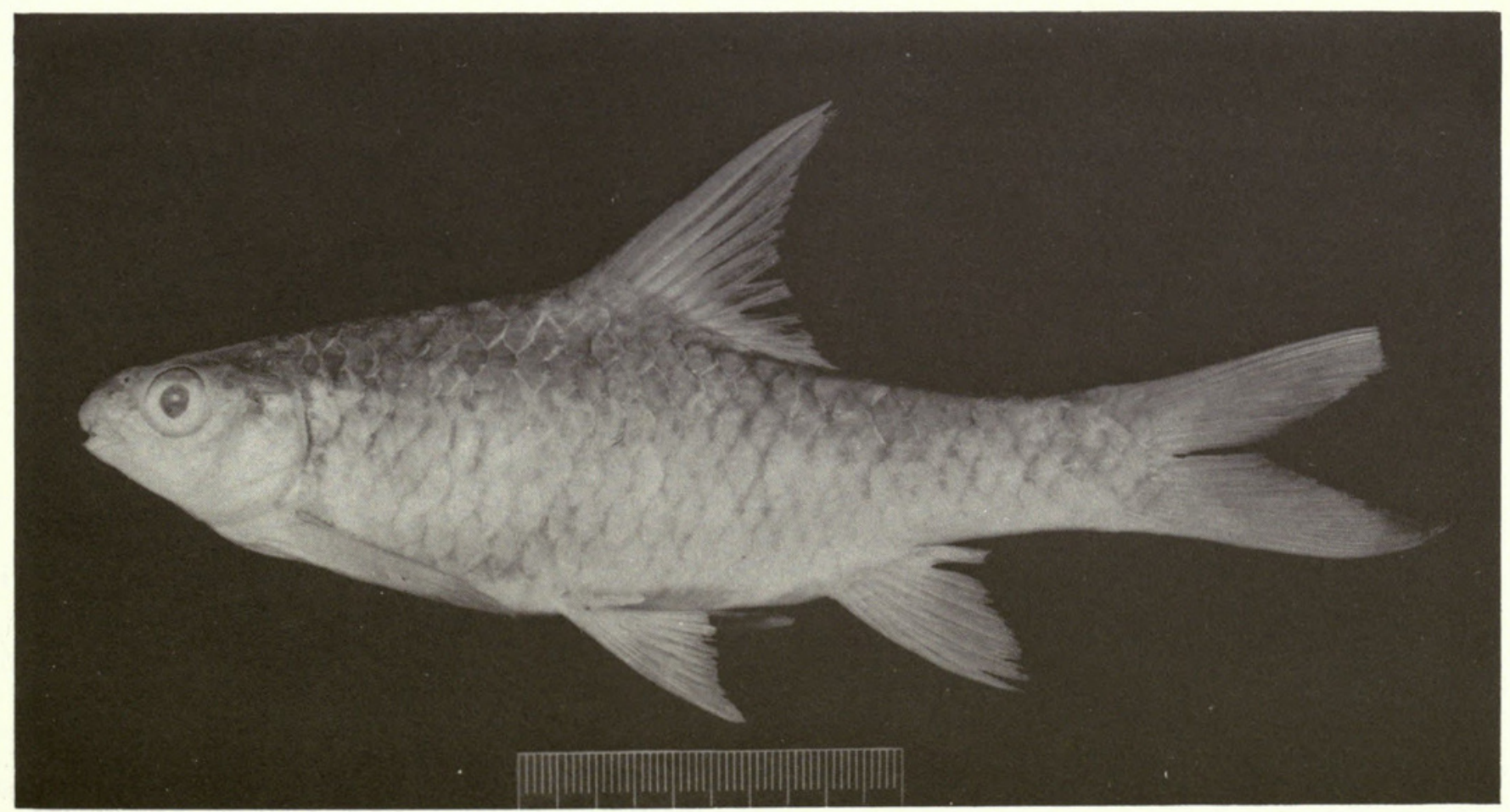

Fig. 1 The holotype of Varicorhinus jubae. 


\section{Description}

The description is based on the three fishes noted above. Measurements and abbreviations conform to those detailed in Banister, 1973. Apart from the standard length itself, all figures are a percentage of the standard length.

\begin{tabular}{|c|c|c|c|}
\hline SL & $135 \mathrm{~mm}$ & $101 \mathrm{~mm}$ & $77 \mathrm{~mm}$ \\
\hline D & $30 \cdot 6$ & $27 \cdot 3$ & $26 \cdot 3$ \\
\hline $\mathrm{H}$ & $23 \cdot 3$ & $23 \cdot 3$ & $24 \cdot 7$ \\
\hline I & 5.9 & $6 \cdot 4$ & $7 \cdot 3$ \\
\hline IO & $8 \cdot 5$ & $7 \cdot 9$ & $7 \cdot 6$ \\
\hline MW & 8.9 & $.7 \cdot 9$ & 8.6 \\
\hline Pct & $23 \cdot 7$ & 21.8 & $21 \cdot 4$ \\
\hline $\mathrm{Cpl}$ & $18 \cdot 5$ & $19 \cdot 3$ & $17 \cdot 8$ \\
\hline $\mathrm{Cpd}$ & $12 \cdot 2$ & $10 \cdot 9$ & $11 \cdot 7$ \\
\hline Snt & $8 \cdot 1$ & $7 \cdot 4$ & $7 \cdot 2$ \\
\hline $\mathrm{Ab}$ & $2 \cdot 9$ & 1.9 & $2 \cdot 6$ \\
\hline $\mathrm{Pb}$ & $3 \cdot 7$ & $2 \cdot 9$ & $4 \cdot 5$ \\
\hline Dsp & 31.9 & $32 \cdot 6$ & $30 \cdot 3$ \\
\hline
\end{tabular}

The head is short and the snout bluntly rounded. The body is relatively deep and, in the largest specimen, gives the fish the appearance of having been a powerful swimmer. The two smaller specimens are more fusiform. Two pairs of short barbels are present. Small, offwhite tubercles are distributed over the sides of the snout in all three fishes.

The mouth is wide and ventral. The lower jaw is short, its anterior edge gently curved and covered with a sharp-edged horny sheath (Fig. 2). The $101 \mathrm{~mm} \mathrm{SL} \mathrm{specimen} \mathrm{has} \mathrm{a} \mathrm{gut}$ length of $200 \mathrm{~mm}$ (the same length as in a sympatric Barbus gananensis of $103 \mathrm{~mm} \mathrm{SL}$ ). All the specimens are either sexually immature or quiescent. There are 39(f1) or 40(f2) vertebrae including those of the Weberian mechanism.

Dorsal fin. There are four unbranched and 10 branched rays (f3). The last unbranched ray is ossified into a stout, straight, smooth spine. When erect, the dorsal margin of the fin is concave. A low sheath of scales envelops the base of the fin. The first ray is in advance of the vertical from the pelvic fin origin.

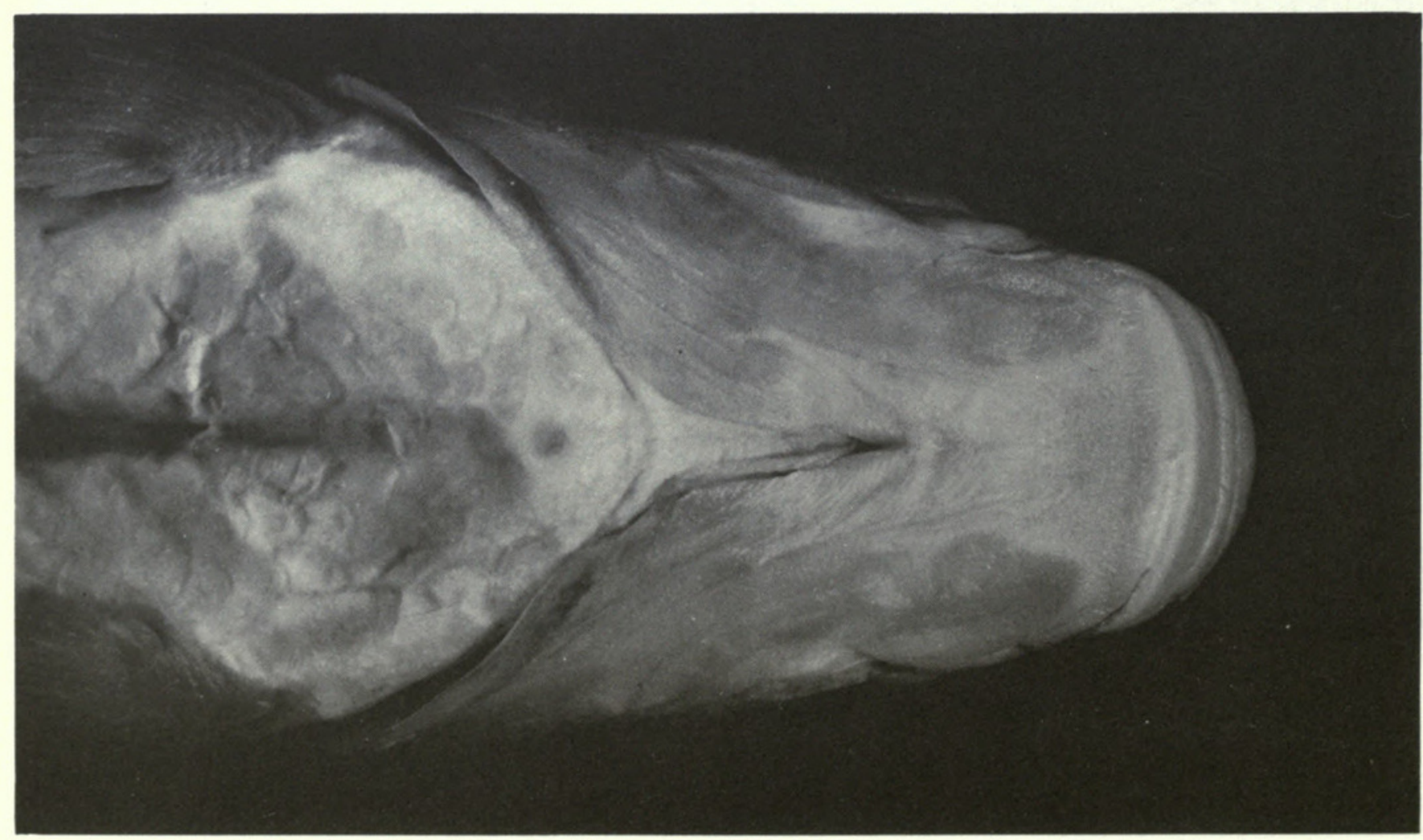

Fig. 2 Ventral view of the head of the holotype of Varicorhinus jubae. 


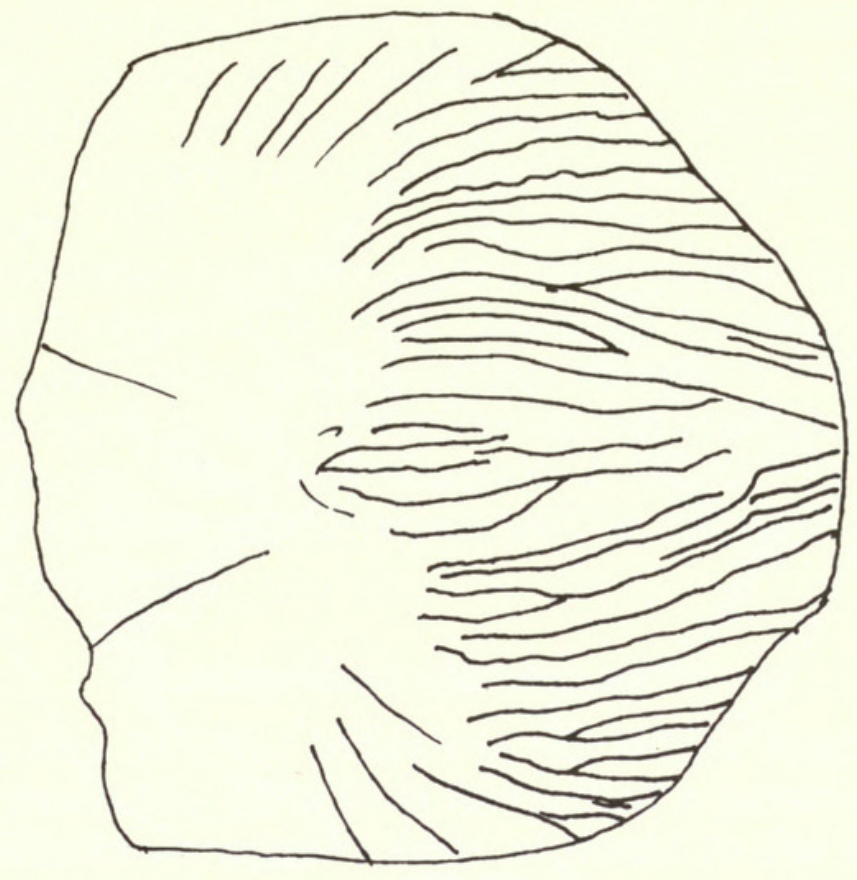

\section{$4 \mathrm{~m} \mathrm{~m}$}

Fig. 3 The striations of the fifth scale from the row above the lateral line of the holotype.

The Anal fin has three unbranched and five branched rays (f3). The last branched ray of the holotype is split to the base giving the appearance of a sixth ray.

Squamation. In the lateral line series there are 26, 27 and 31 scales. From the dorsal midline to the lateral line there are $4 \frac{1}{2}(\mathrm{f} 3)$ scales and from there to the ventral mid-line also $4 \frac{1}{2}$ (f3) scales. There are 12 (f3) scales around the least circumference of the caudal peduncle. Between the lateral line and the pelvic fin base there are $1 \frac{1}{2}$ (f2) or $2 \frac{1}{2}$ scales. The pattern of the scale striations is shown in Fig. 3.

Pharyngeal bones and teeth. The pharyngeal teeth number 2.3.5-5.3.2 (f3). The pharyngeal bone is depicted in Fig. 4 where it can be seen that it is smaller than that of an equivalently sized Barbus gananensis.

Gill rakers. On the lower limb of the first gill arch there are 16 (f1) or 17 (f2) long, hooked gill rakers.

Coloration. Alcohol preserved specimens are dark grey-brown dorsally, silver-grey laterally and pale grey ventrally. The fins are pale grey. In life, the fishes were intensely silver, darkening dorsally.

DisTRIBUTION. This species is known only from the type locality.

\section{Comparison with Barbus gananensis}

The last re-description of Barbus gananensis (Banister, 1973) was based on only three longpreserved specimens so the extra ten specimens mentioned above (BMNH 1976.7.1:3-12) were very useful. These specimens $71 \mathrm{~mm}$ to $125 \mathrm{~mm}$ SL have shallower caudal peduncles $(11 \cdot 0-12 \cdot 9$ cf $13 \cdot 1-15 \cdot 0 \% \mathrm{SL})$ than the previous sample as well as fewer lateral line scales (26 (f5), 27 (f3), 28 (f1) and 29 (f1) $c f 29$ (f2) or 31 (f1) suggesting that the previously reported range may be atypical. All other counts and measurements lie within the published limits but the head length, snout length and the length of both pairs of barbels lie at the upper ends of the ranges.

In overall appearance, Varicorhinus jubae and Barbus gananensis resemble each other more closely than either does its respective congeners. Although such resemblances are unquantifiable, the reality can be seen by comparing Figs $1 \& 6$. The head is excluded from these comments. 


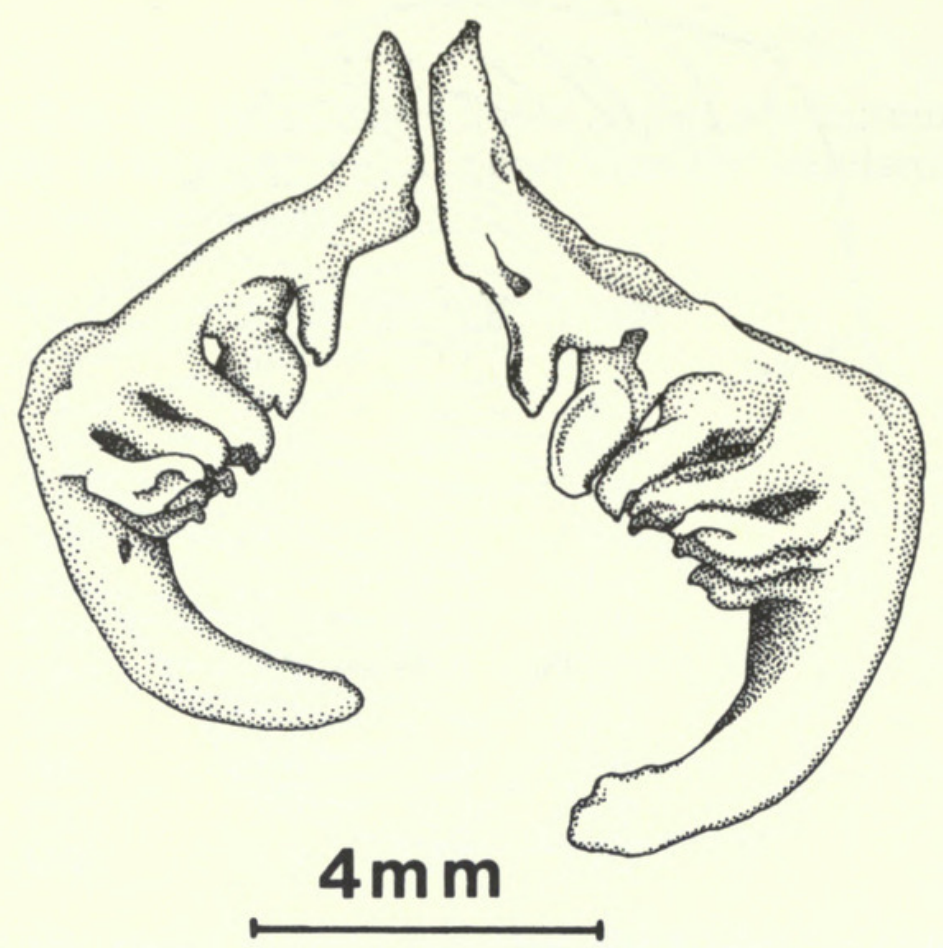

Fig. 4 Comparison of the pharyngeal bones of Varicorhinus jubae $101 \mathrm{~mm}$ SL (left), and Barbus gananensis $103 \mathrm{~mm}$ SL.

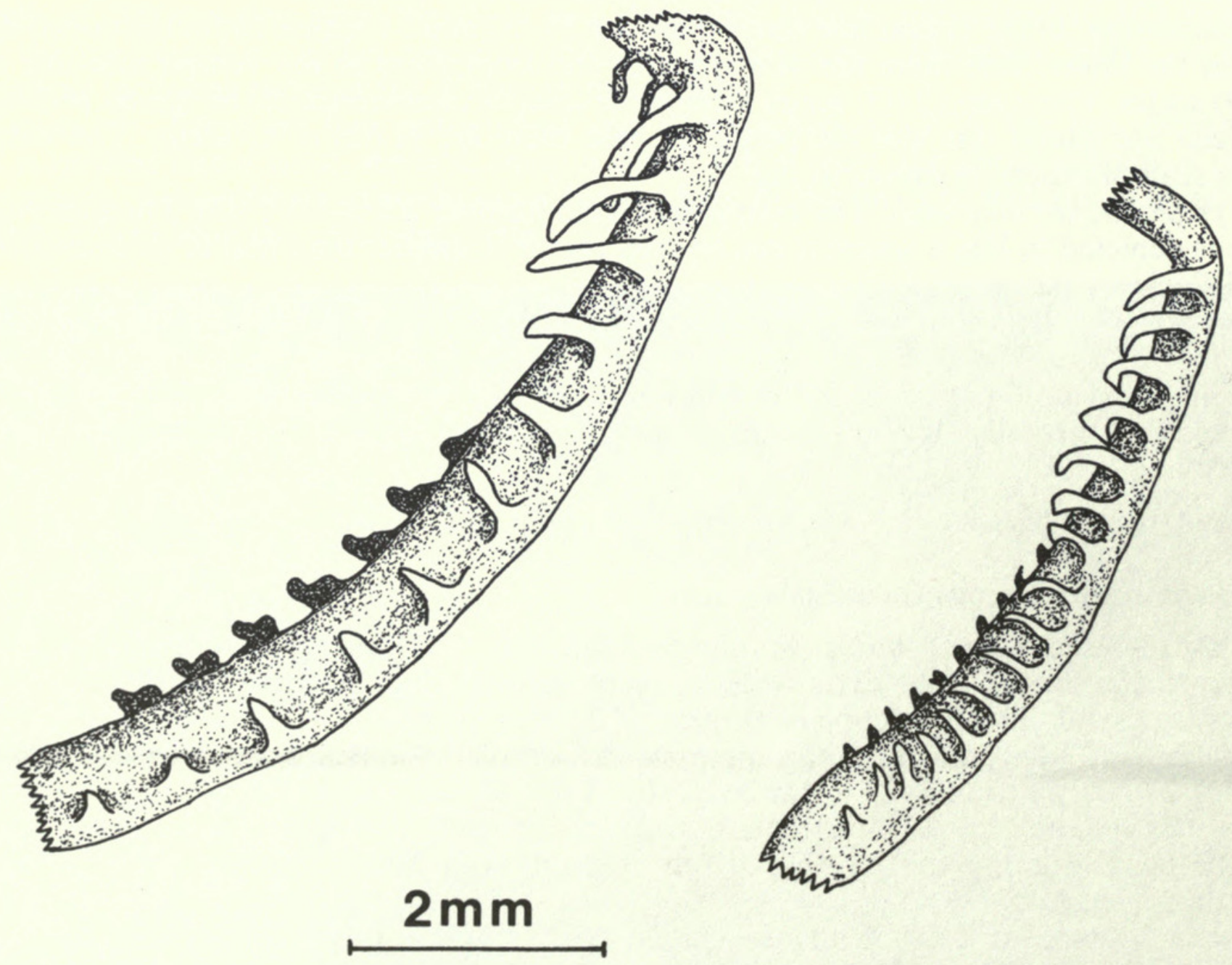

Fig. 5 The gill rakers on the first ceratobranchial of Barbus gananensis (A) $103 \mathrm{~mm} \mathrm{SL}$, and Varicorhinus jubae (B) $101 \mathrm{~mm}$ SL. 
The most conspicuous differences between $V$. jubae and B. gananensis occur in characters related to feeding. The wide mouth, sharp edge to the lower jaw, smaller barbels and higher number of gill rakers in the new species are all characters that are associated with scraping, epilithic dietary habits. The disparity in the pharyngeal bone size has been noted above and further discussed in Banister, 1972.

The presence of a Varicorhinus species bearing a close superficial resemblance to a sympatric Barbus species has been observed in other instances. Varicorhinus ruwenzorii from the Ruimi river, Uganda, has the same striking colour pattern as Barbus somereni (Banister, 1972). From the Upemba region of Zaire a similar pairing phenomenon is shown by Varicorhinus upembensis and Barbus gestetneri (Banister \& Bailey, 1979). Although I have no immediate explanation for this, the phenomenon will be treated in detail in the reassessment of the genus referred to above.

\section{Varicorhinus clarkeae sp. nov.}

Holotype. A fish of $151 \mathrm{~mm}$ SL, No. 164456 in the Musée Royale de l'Afrique Centrale, Tervuren, Belgium. Specimen No. 164457 is designated a paratype. Both specimens (previously registered as Varicorhinus ensifer) were collected in the Rio Cunje, an affluent of the Cuanza, Ceilunga, Angola.

ETYMOLOGY. Named in honour of Mrs Margaret Clarke who gave so much assistance during the course of these researches.

\section{Description}

Based on the two specimens of 151 and $161 \mathrm{~mm} \mathrm{SL}$. The morphometric data (holotype first) is as follows: $\mathrm{D}=22 \cdot 5,23 \cdot 6 ; \mathrm{H}=20 \cdot 5,20 \cdot 5 ; \mathrm{I}=4 \cdot 0,6 \cdot 3 ; \mathrm{IO}=8 \cdot 0,7 \cdot 5 ; \mathrm{MW}=7 \cdot 3,6 \cdot 8$; Pct $=19 \cdot 3 ; 18 \cdot 6 ; \mathrm{Cpl}=14 \cdot 6,18 \cdot 0 ; \mathrm{Cpd}=9 \cdot 3,10 \cdot 6 ; \mathrm{Snt}=7 \cdot 3,6 \cdot 8 ; \mathrm{Ab}=1 \cdot 7,1 \cdot 0 ; \mathrm{Pb}=3 \cdot 6,2 \cdot 5 ;$ Dfin $=21 \cdot 8,18 \cdot 0$.

The body is shallow and nearly circular in cross section. The lower jaw has a slightly curved anterior edge is covered with a thin horny layer. Papillae are present on both lips, those on the upper lip decrease in size anteriorly and are larger than those on the lower jaw which are confined to a strip behind the horny sheath. The snout is fleshy and a thin

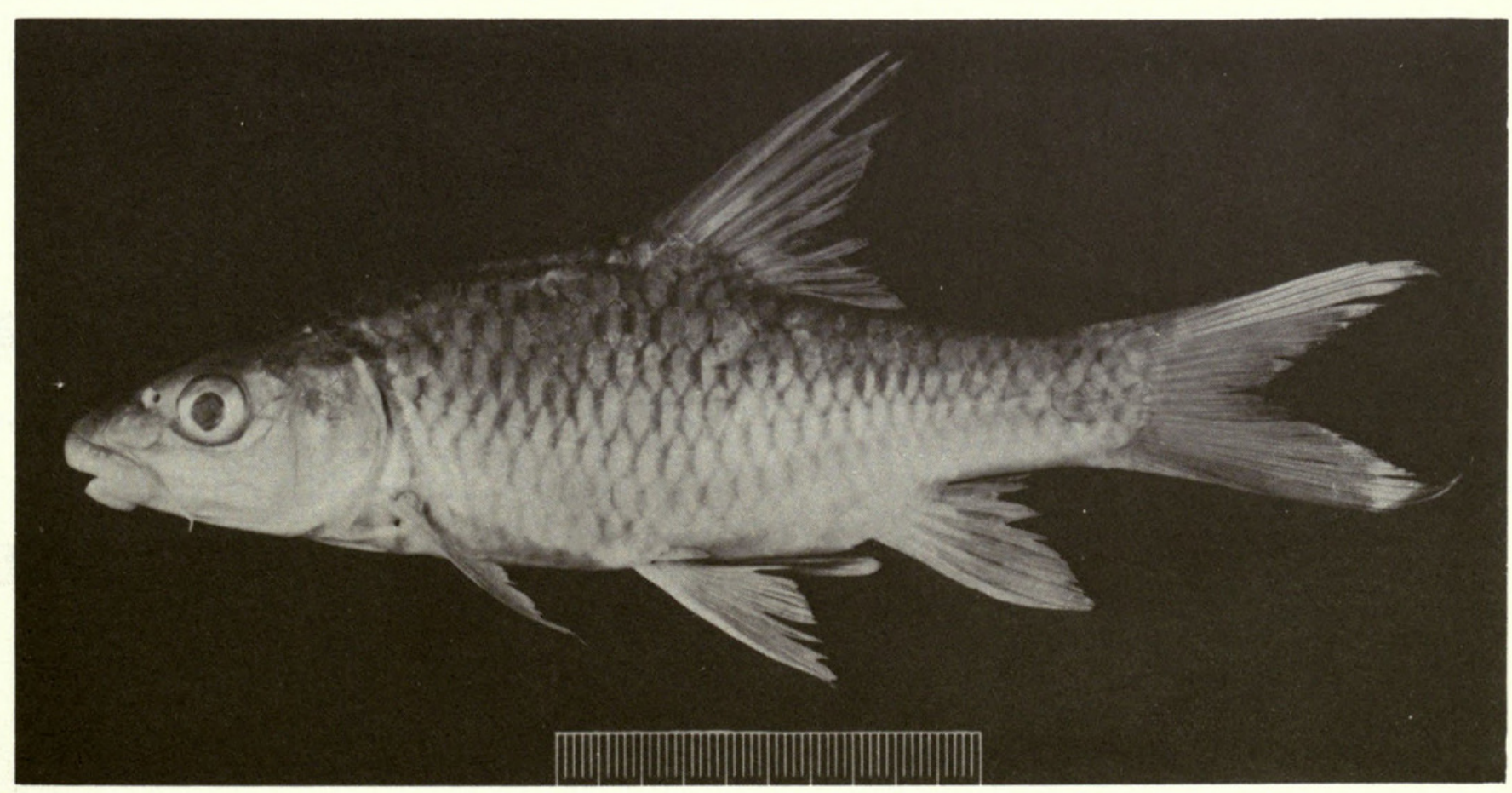

Fig. 6 Barbus gananensis $103 \mathrm{~mm} \mathrm{SL}$. 
ventral flap covers the anterior edge of the upper jaw. There are no tubercles nor tubercle scars on the snout but what could be scars of small tubercles are present on the skin covering the lachrymal bone in the holotype. Two pairs of small barbels are present. There are 41(f2) vertebrae, including those of Weberian mechanism.

Dorsal fin. There are 4 unbranched and 9 branched rays (f2). The last unbranched ray is ossified into a thin, short, straight spine. There is no raised sheath of scales around the base of the dorsal fin.

The Anal fin has three unbranched and five branched rays (f2).

Squamation. The lateral line has 33 or 35 scales and is relatively high on the body (see below). There are $5 \frac{1}{2}$ (f2) scales between the dorsal mid-line and the lateral line and $5 \frac{1}{2}$ (f2) from there to the ventral mid-line. Three scales lie between the lateral line and the pelvic fin (f2). Twelve scales encircle the least circumference of the caudal peduncle. The scale striations are parallel.

Gill rakers. There are 16 gill rakers on the lower limb of the first gill arch of the holotype.

Pharyngeal bones and teeth. The pharyngeal teeth number 2.3.5-5.3.2. The posterior faces of the crown of the second and third teeth of the inner row (I2 \& I3 in the system of Banister \& Clarke, 1980) have a horseshoe shaped ridge which becomes exaggerated on I4, I5, II2 and II3.

Coloration. In alcohol preserved specimens the back is dark brown, the belly and flanks lighter brown. The demarcation between the two browns is very marked on the posterior part of the fish.

Distribution. Known only from Cunaza, Ceilunga, Angola, approximately $12^{\circ} 00^{\prime} \mathrm{S}$, $17^{\circ} 40^{\prime} \mathrm{E}$.

\section{Diagnosis and affinities}

The presence of papillae on the lips and a horny edge to the lower jaw suggests an affinity with Varicorhinus ensifer Boulenger and the species described below as this combination of features appears to be unique to these three species. Varicorhinus clarkeae can be distinguished from $V$. ensifer by a shorter, thinner dorsal fin spine and a more cylindrical body.

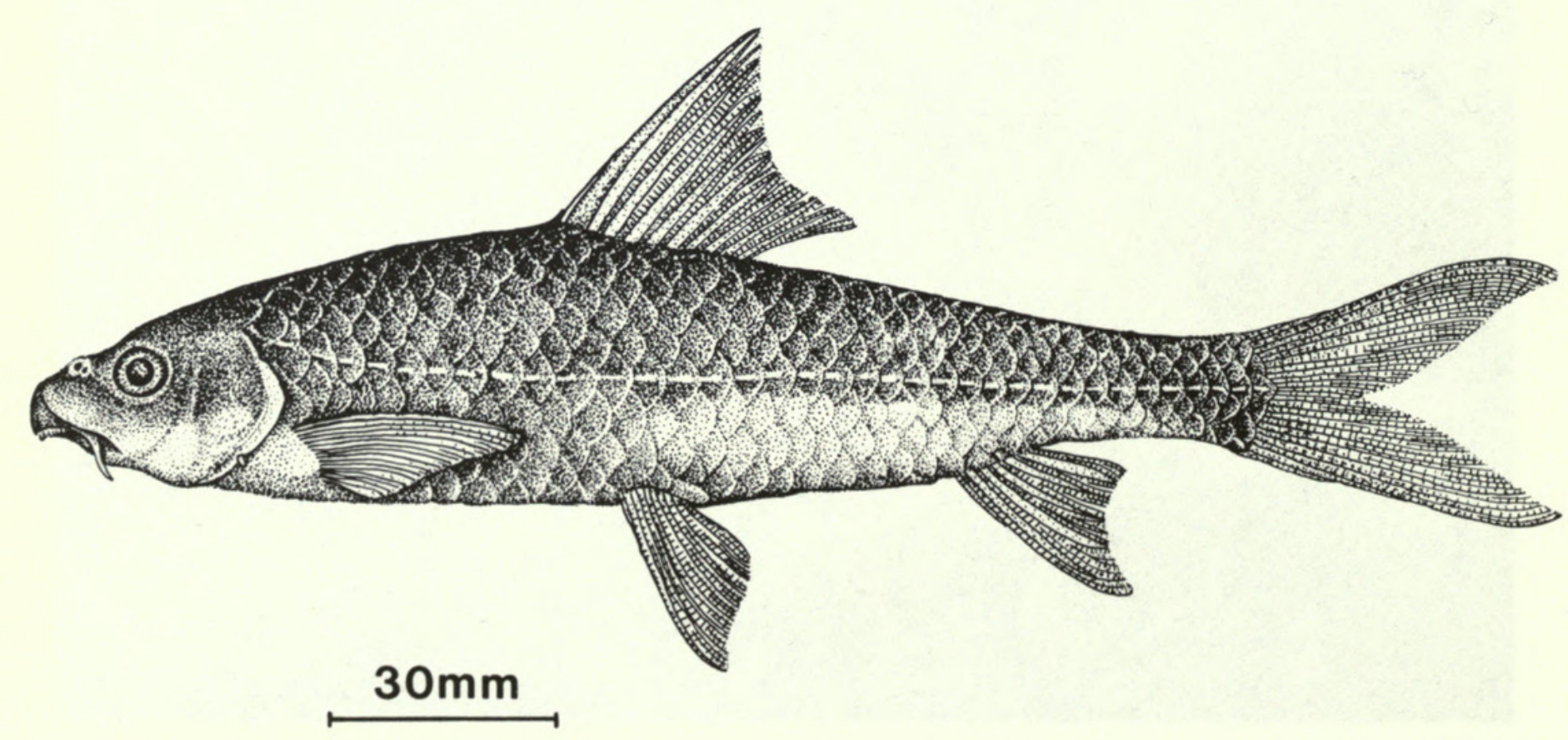

Fig. 7 Varicorhinus clarkeae the holotype. 
Varicorhinus robertsi $\mathrm{sp}$. nov.

TYPICAL SERIES. Holotype, a fish of $65 \mathrm{~mm}$ SL from the Sanga waterfalls at the tailwaters of the hydroelectric dam at Sanga on the Inkisi river, Zaire, BMNH 1983.3.30:20; paratypes 18 specimens $38 \cdot 7-64 \cdot 0 \mathrm{~mm}$ SL from the same locality, BMNH 1983.3..30.21-38. All the specimens were collected by Drs Tyson Roberts and Don Stewart on June 261973.

Etymology. Named after the ichthyologist and collector Dr Tyson Roberts.

\section{Description}

The description is based on the 19 specimens listed above.

\begin{tabular}{lcccc} 
& & & & \multicolumn{1}{r}{$\begin{array}{c}\text { range } \\
\mathrm{mm}\end{array}$} \\
$\mathrm{L}$ & $\mathrm{x}$ & s.d & s.e. & $38 \cdot 7-65 \cdot 0$ \\
$\mathrm{D}$ & $26 \cdot 0$ & $1 \cdot 3$ & $0 \cdot 3$ & $24 \cdot 1-28 \cdot 8$ \\
$\mathrm{H}$ & $25 \cdot 8$ & $1 \cdot 1$ & $0 \cdot 3$ & $23 \cdot 4-27 \cdot 8$ \\
$\mathrm{I}$ & $7 \cdot 0$ & $0 \cdot 9$ & $0 \cdot 2$ & $5 \cdot 9-8 \cdot 4$ \\
$\mathrm{IO}$ & $6 \cdot 2$ & $0 \cdot 6$ & $0 \cdot 1$ & $5 \cdot 2-7 \cdot 4$ \\
$\mathrm{MW}$ & $5 \cdot 8$ & $1 \cdot 0$ & $0 \cdot 2$ & $5 \cdot 9-9 \cdot 6$ \\
$\mathrm{Pct}$ & $22 \cdot 1$ & $1 \cdot 0$ & $0 \cdot 2$ & $20 \cdot 2-24 \cdot 2$ \\
$\mathrm{Cpl}$ & $17 \cdot 7$ & $1 \cdot 3$ & $0 \cdot 3$ & $15 \cdot 5-20 \cdot 8$ \\
$\mathrm{Cpd}$ & $10 \cdot 5$ & $0 \cdot 5$ & $0 \cdot 1$ & $9 \cdot 4-11 \cdot 7$ \\
$\mathrm{Snt}$ & $8 \cdot 4$ & $0 \cdot 5$ & $0 \cdot 1$ & $7 \cdot 6-9 \cdot 4$ \\
$\mathrm{Ab}$ & + & - & - & - \\
$\mathrm{Pb}$ & $2 \cdot 3$ & $0 \cdot 3$ & $0 \cdot 1$ & $1 \cdot 6-2 \cdot 7$ \\
$\mathrm{Dfin}$ & $29 \cdot 1$ & $2 \cdot 6$ & $0 \cdot 6$ & $25 \cdot 2-34 \cdot 4$
\end{tabular}

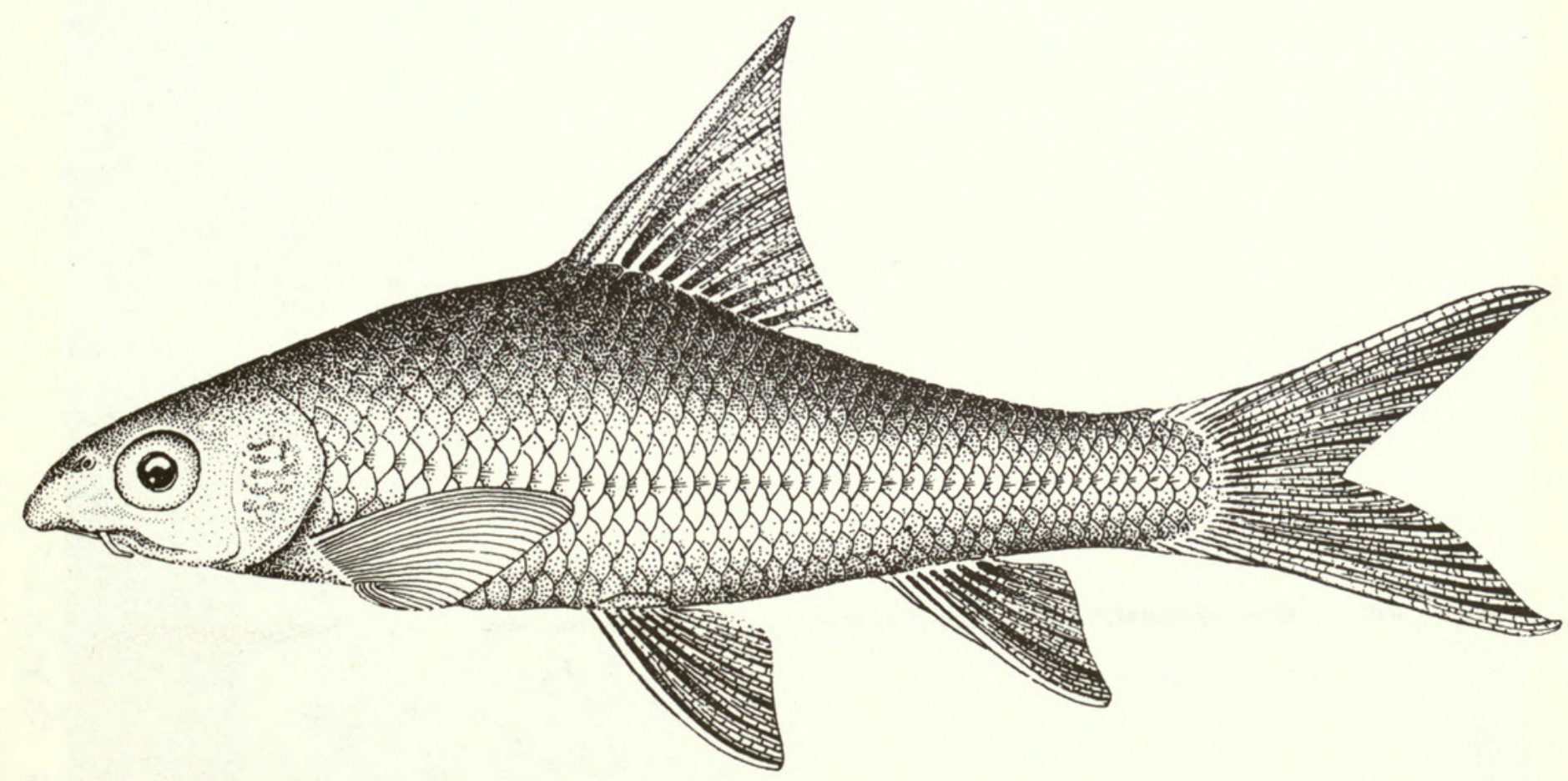

Fig. 8 Varicorhinus robertsi the holotype. 
A further 9 specimens were collected $(18.4-38.7 \mathrm{~mm} \mathrm{SL})$ but are not included in this description because their poor condition precluded accurate measurement.

The body is compressed, its greatest depth is immediately in front of the dorsal fin. The dorsal profile is more convex than the ventral profile. The snout is fleshy, rounded and extends in front of the mouth. The ventral face of the head is concave just behind the mouth. The upper jaw bears rows of papillae (Fig. 9), one row appears on the lip of small fishes (circa $30 \mathrm{~mm} \mathrm{SL}$ ) and the number of rows increases with size. The lower jaw has papillae behind the sharp-edged horny sheath. None of the specimens has tubercules. There are minute anterior barbels. In the ten specimens radiographed there are 38 (f1), 39 (f5) or 40 (f4) vertebrae including those of the Weberian mechanism.

Dorsal fin. There are 4 (f19) unbranched and 8 (f2) or 9 (f17) branched rays. The last simple ray is formed into a thin, smooth spine. The dorsal fin origin is anterior to that of the pelvic fin. The anal fin has 3 unbranched and 5 (f19) branched rays.

Squamation. In the lateral line there are 39 (f9), 40 (f5), 41 (f4) or 43 (f1) scales. From the dorsal mid-line to the lateral line there are $6 \frac{1}{2}$ (f12) or $7 \frac{1}{2}$ (f5) scales and from there to the ventral mid-line $6 \frac{1}{2}$ (f4) or $7 \frac{1}{2}$ (f14) scales. Between the lateral line and the pelvic fin base there are 4 (f4), $4 \frac{1}{2}$ (f13) or 4 (f2) scales. Eighteen (f1) or 16 (f16) scales encircle the least circumference of the caudal peduncle. Scale counts were not obtainable on all specimens. There are few striations on the scales and their disposition is shown in Fig. 10.

Pharyngeal bones and teeth. The teeth number 2.3.5-5.3.2. The last tooth on the inner row (I5) has a conspicuous sulcus on the crown in the plane of the tooth. The pharyngeal bone is shown in Fig. 11.

Gill rakers. There are 10 (f1), 11 (f3) or 12 (f3) on the lower limb of the first gill arch in the 7 specimens examined.

Coloration. The body colour in alcohol preserved specimens is pale brown, only slightly darker on the back than on the belly. A narrow, dark strip covers the ridge of the back from

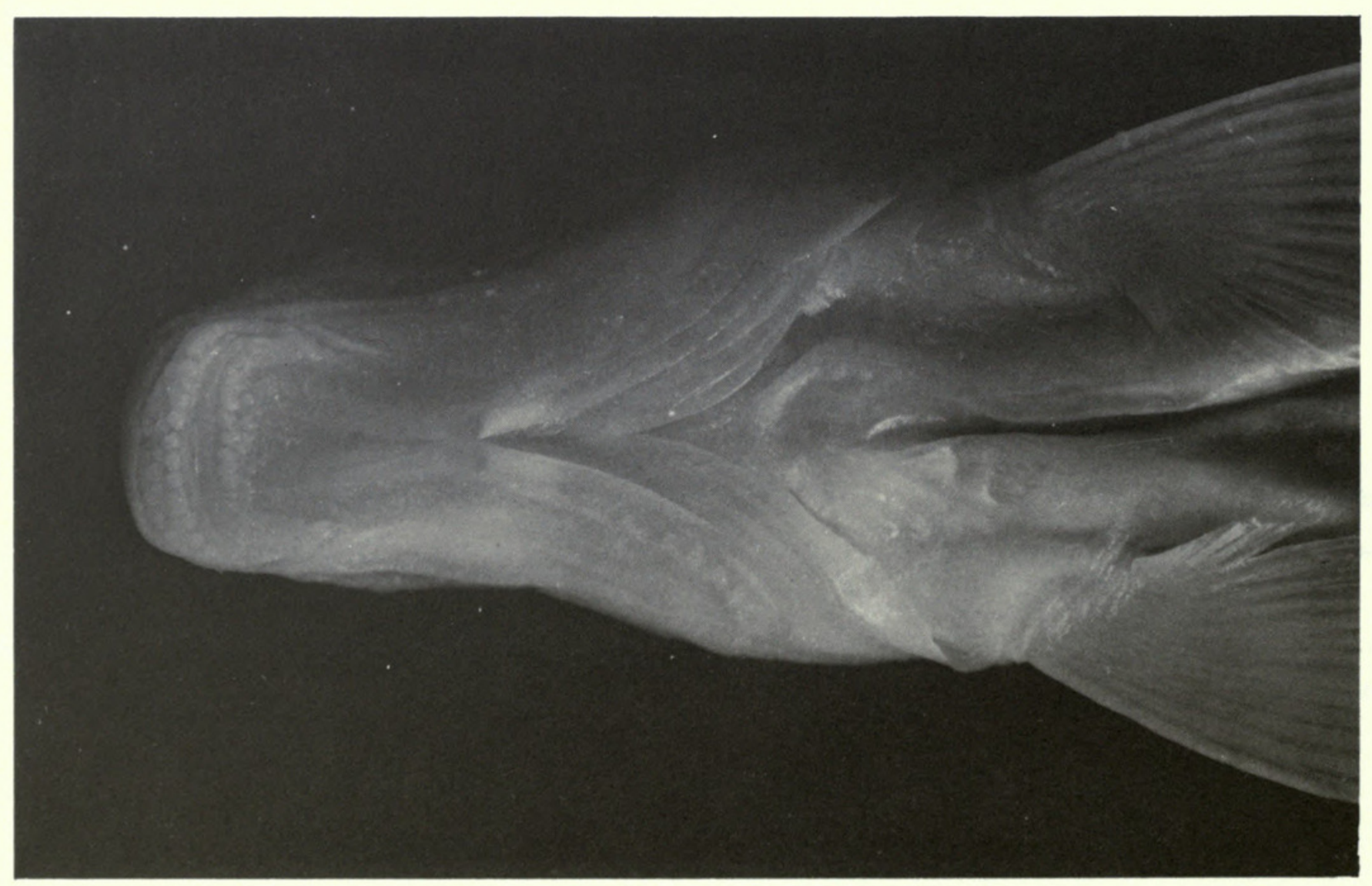

Fig. 9 Ventral view of the head of the holotype of Varicorhinus robertsi to show the papillae. 


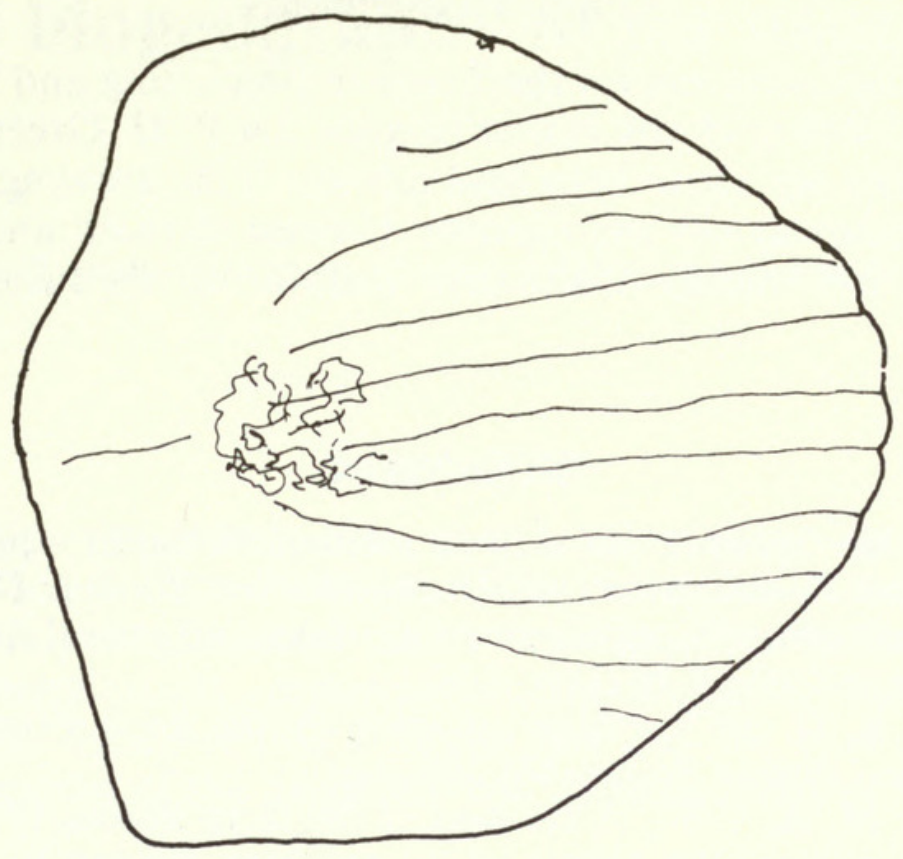

$1 \mathrm{~mm}$

Fig. 10 The fifth scale from the row above the lateral line of the holotype of Varicorhinus robertsi.

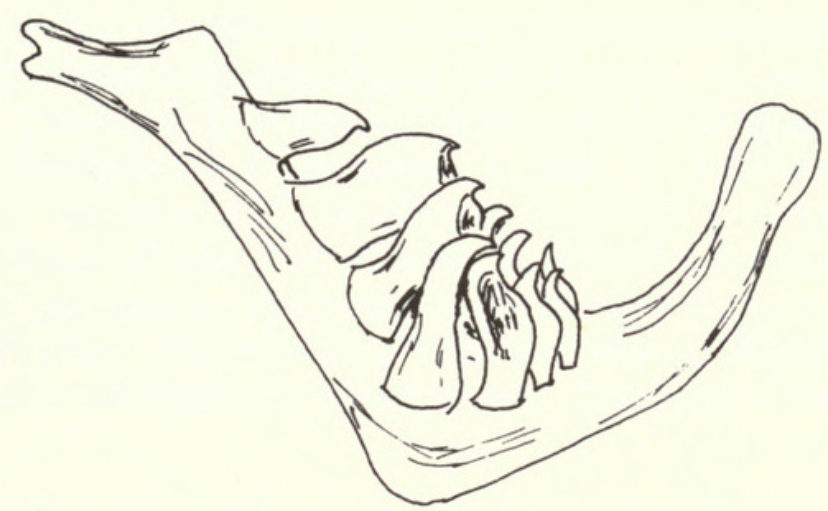

$2 \mathrm{~mm}$

Fig. 11 Varicorhinus robertsi pharyngeal bone from the largest paratype.

the occipital region to the dorsal fin origin. The smaller specimens have a dark spot at the base of the tail fin. The centre of the operculum is transparent and the gills are visible through it. The paired fins are hyaline. The caudal fin lobes have a streak of dark pigment and the dorsal fin has a dark, dorsal margin. The live colour is unknown.

Distribution. This species is known only from the type locality, the Sanga waterfalls, $4^{\circ} 50^{\prime} \mathrm{S}, 14^{\circ} 47^{\prime}$ E. Zaire.

Diagnosis. From the other Varicorhinus species with papillae on the lips this species is easily distinguished by the presence of smaller scales. 


\section{Acknowledgements}

Firstly, I wish to thank the collectors for their care in preserving and bringing back the specimens. Secondly, I would like to thank my colleagues, Dr P. H. Greenwood, Mr G. J. Howes and Mrs Margaret Clarke for their help and advice. The drawings are the work of Jack Shroeder (7), Mandy Holloway (8) and Gordon Howes: to them and the photographer, $\mathrm{Mr}$ Paul Richens, I extend my thanks. I am very grateful to Ms Julie Hacker for typing the manuscript.

\section{References}

Banister, K. E. 1972. On the cyprinid fish Barbus alluaudi Pelegrin: a possible intergeneric hybrid from Africa. Bulletin of the British Museum (Natural History) Zoology 24 (5): 261-290.

- A revision of the large Barbus (Pisces, Cyprinidae) of east and central Africa. Bulletin of the British Museum (Natural History) Zoology 26 (1): 1-148.

Banister, K. E. \& Bailey, R. G. 1979. Fishes collected by the Zaire River Expedition, 1974-1975. Zoological Journal of the Linnean Society 66: 205-249.

Banister, K. E. \& Clarke, M. A. 1980. A revision of the large Barbus (Pisces, Cyprinidae) of Lake Malawi with a reconstruction of the history of the southern African Rift Valley lakes. Journal of Natural History 14: 483-542. 


\section{$2 \mathrm{BHL}$ Biodiversity Heritage Library}

Banister, Keith Edward. 1984. "Three new species of Varicorhinus (Pisces, Cyprinidae) from Africa." Bulletin of the British Museum (Natural History) Zoology 47, 273-282. https://doi.org/10.5962/bhl.part.21839.

View This Item Online: https://www.biodiversitylibrary.org/item/19472

DOI: https://doi.org/10.5962/bhl.part.21839

Permalink: https://www.biodiversitylibrary.org/partpdf/21839

\section{Holding Institution}

Natural History Museum Library, London

\section{Sponsored by}

Natural History Museum Library, London

\section{Copyright \& Reuse}

Copyright Status: In copyright. Digitized with the permission of the rights holder.

Rights Holder: The Trustees of the Natural History Museum, London

License: http://creativecommons.org/licenses/by-nc-sa/4.0/

Rights: http://biodiversitylibrary.org/permissions

This document was created from content at the Biodiversity Heritage Library, the world's largest open access digital library for biodiversity literature and archives. Visit BHL at https://www.biodiversitylibrary.org. 